\title{
Stimulation of a rat uterine stromal cell line in culture reveals a molecular switch for endocrine-dependent differentiation
}

\author{
V Rider, T Potapova, G Dai ${ }^{1}$ and $\mathbf{M}$ J Soares ${ }^{1}$ \\ Department of Biology, Pittsburg State University, Pittsburg, Kansas 66762, USA \\ ${ }^{1}$ Institute of Maternal-Fetal Biology and Division of Cancer and Developmental Biology, Department of Pathology and Laboratory Medicine, \\ University of Kansas Medical Center, Kansas City, Kansas, USA \\ (Requests for offprints should be addressed to V Rider; Email: VRider@pittstate.edu)
}

\begin{abstract}
Differentiation of uterine stromal cells is critical for the establishment of pregnancy. This study had two purposes: (i) to validate the use of the UIII rat uterine stromal cell model for investigating mechanisms underlying decidual cell differentiation, and (ii) to use this cell model to identify a molecular switch for cellular entry into the decidual cell differentiation pathway. Quiescent rat uterine stromal cells were transfected with a $500 \mathrm{bp}$ segment of the decidual prolactin-related protein (dPRP) promoter ligated to a luciferase reporter gene. Cells were incubated in low-serum medium, or in low-serum medium containing progesterone $(1 \mu \mathrm{M})$, estradiol $17-\beta(10 \mathrm{nM})$, cholera toxin $(10 \mathrm{ng} / \mathrm{ml})$ and interleukin-11 $(10 \mathrm{ng} / \mathrm{ml})$. Protein extracts were collected $48 \mathrm{~h}$ later and luciferase was
\end{abstract}

measured in the cellular lysates. Cholera toxin and interleukin-11 stimulated luciferase expression $(P<0 \cdot 05)$ and addition of sex steroids further increased $(P<0 \cdot 05)$ dPRP promoter activity. Stromal cells did not proliferate $(P>0 \cdot 05)$ under differentiation conditions. Deletion analysis of the dPRP promoter revealed maximal luciferase expression between -250 and $-500 \mathrm{bp}$ relative to the transcription start site. Comparison of cyclin E/Cdk2 activity between proliferating and differentiating cells showed a 3-fold increase $(P<0 \cdot 05)$ at $12 \mathrm{~h}$ in differentiating cells. The results suggest that cyclin E/Cdk2 serves as a molecular switch for uterine stromal cell entry into the decidual cell differentiation pathway.

Journal of Endocrinology (2005) 184, 119-127

\section{Introduction}

The female sex steroids progesterone and estradiol change the mammalian uterus from a hostile environment to one that is receptive to the early embryo (Chang 1950, Psychoyos 1973). The degree of uterine remodeling depends on the type of placentation that is characteristic for a given species (Amaroso 1952). In both humans and rodents the endometrium is extensively remodeled because the embryo not only attaches to the epithelium, but it also penetrates the basal lamina and invades the uterine stroma (Pijnenborg et al. 1981). Preparation of the stromal compartment requires a complex action of both estradiol and progesterone to stimulate the proliferation and differentiation of stromal cells. These differentiated stromal cells form the maternal interface with the placenta and make up a tissue referred to as the decidua (Bell 1983). The importance of decidualization for successful pregnancy is now irrefutable because mice lacking genes that are essential for stromal cell differentiation cannot maintain pregnancy (Lydon et al. 1995, Gendron et al. 1997, Lim et al. 1997, Bilinski et al. 1998, Robb et al. 1998, Ashkar et al. 2000, Yao et al. 2003).
Recent evidence suggests that interleukin-11 (IL-11), a cytokine that acts on a wide range of cellular processes (Salamonson et al. 2003), plays a central role in decidualization. Mice lacking the IL-11 receptor are infertile owing to the failure of the stromal cells to undergo decidualization (Bilinski et al. 1998, Robb et al. 1998). IL-11 mRNA is induced in the uterine stroma at implantation initiation in the rat, while its receptor and glycoprotein gp130 are constitutively expressed throughout the primary and secondary decidua (Li et al. 2001). Human uterine stromal cells cultured in medium containing progesterone produce IL-11 and prolactin (PRL) mRNA (Dimitriadis et al. 2002). Neutralization of IL-11 using antibodies reduces PRL and insulin-like growth factor-binding protein-1 (IGFBP-1) production, while addition of IL-11 to progesterone-containing cultures increases PRL and IGFBP-1 secretion.

PRL, IGFBP-1 and tissue factor are sensitive markers for differentiating human stromal cells (Irwin et al. 1989, Tseng et al. 1992, Lockwood et al. 1993, Christian et al. 2001). The tissue-specific expression of human PRL occurs by utilization of an alternative promoter region that becomes activated in differentiating cells 
(Berwaer et al. 1994, Telgmann \& Gellersen 1998). In the rat, at least 20 different genes that are structurally related to PRL are expressed in decidual cells and/or the trophoblast cells of the chorioallantoic placenta (Soares \& Linzer 2001, Öztürk et al. 2003, Wiemers et al. 2003). Decidual PRL-related protein (dPRP) is expressed in rat decidual cells but not stromal cells (Roby et al. 1993, Orwig et al. 1997, Rasmussen et al. 1997). The dPRP protein does not activate the PRL receptor signaling pathways but, instead, it interacts with heparin and may influence inflammatory cells within the uterine compartment (Wang et al. 2000).

Signal transduction pathways that regulate stromal cell differentiation remain largely unknown. Cholera toxin has been used to induce decidualization in both the mouse and rat uterus (Kennedy 1983, Rankin et al. 1988), although its mechanism of action is not known. Cholera toxin stimulates prostaglandin $\mathrm{E}_{2}$ synthesis in other cell types by increasing the expression of phospholipase $\mathrm{A}_{2}$-activating protein (Peterson et al. 1996), suggesting that cholera toxin may stimulate differentiation of rodent uterine stromal cells, in part, by mechanisms that involve increased prostaglandin $\mathrm{E}_{2}$ production (Kennedy 1983, 1985).

At the time of embryo implantation in the rat, there is a switch in cellular proliferation from epithelial to stromal compartments (Rider \& Psychoyos 1994). Stromal cells do not divide without progesterone, and implantation in mice lacking the progesterone receptor fails, in part, because the uterine stromal cells cannot undergo differentiation (Lydon et al. 1995). Previous research in our laboratory (Piva et al. 1996, Rider et al. 1998, Jones et al. 2000, Rider 2002) was directed towards the isolation and characterization of rat uterine stromal cell lines that could be used to identify hormone-dependent effects on uterine stromal cells. These cell lines (UI-UIII) have been extensively characterized and their response to proliferative agents is consistent and repeatable. Using those cell lines, we found (Jones et al. 2000) that progesterone acts directly on proteins that control transit through the cell cycle. In addition, progesterone plus basic fibroblast growth factor (FGF) sustains the timing of stimulation for transit of uterine stromal cells through G1 into S phase compared with FGF alone (Jones et al. 2000). The data led us to hypothesize that progesterone, acting through its receptor, helps to establish a G1 phase from which differentiation can occur (Rider 2002). We proposed that progesterone extends the G1 phase of the stromal cell cycle, and during this window of opportunity, if uterine stromal cells are stimulated with appropriate agents, then the cells will exit the proliferative cycle and enter into the differentiation pathway. In this present study, we begin to test this hypothesis with two distinct goals: (i) to validate the use of the UIII rat uterine stromal cell model to investigate the mechanisms underlying decidual cell differentiation, and (ii) to use this cell model to identify a molecular switch for cellular entry into the decidual cell differentiation pathway.

\section{Materials and Methods}

\section{Reagents}

Recombinant mouse IL-11 was purchased from R\&D Systems (Minneapolis, MN, USA) and human recombinant basic FGF was from Becton Dickinson Biosciences (Bedford, MA, USA). Fetal bovine serum (FBS) was purchased from Harlan (Madison, WI, USA). Cholera toxin was obtained from Sigma (St Louis, MO, USA). The pGL-2 basic vector (negative control) and a Roux sarcoma virus (RSV) promoter-luciferase reporter plasmid (positive control) were purchased from Promega (Madison, WI, USA). An RSV promoter ligated to a $\beta$-galactosidase $(\beta-G a l)$ reporter gene was cotransfected with all constructs and used to correct for transfection efficiency. Kits for monitoring $\beta-G a l$ activity were obtained from Tropix (Bedford, MA, USA). OPTI-MEM reduced serum medium without phenol red and Lipofectamine reagent were purchased from Life Technologies (Gaithersburg, MD, USA).

\section{Cell culture and proliferation}

Isolation of the uterine stromal cell lines has been described in detail previously (Piva et al. 1996). Cells (UIII) from the same passage (between passages 15 and 25) were used to determine treatment effects within an experiment by propagating a sufficient number of cells for each experiment in Medium 199 containing 10\% FBS (Rider et al. 1998). Quiescence was induced by culturing stromal cells for $72 \mathrm{~h}$ in serum-free, phenol red-free Dulbecco's Modified Eagle medium (Gibco, Grand Island, NY, USA) and MCDB-105 (Sigma) in a 3:1 mixture containing insulin $(5 \mu \mathrm{g} / \mathrm{ml})$ and supplements as detailed elsewhere (Piva et al. 1996). Quiescent cells were stimulated to synchronously re-enter the cell cycle by adding progesterone $(1 \mu \mathrm{M})$, estradiol $17-\beta(10 \mathrm{nM})$ and FGF $(50 \mathrm{ng} / \mathrm{ml})$. Cholera toxin $(10 \mathrm{ng} / \mathrm{ml})$ and IL-11 $(10 \mathrm{ng} / \mathrm{ml})$ were added to some cultures to stimulate differentiation. Doseresponse studies showed that the maximal proliferative response of uterine stromal cells occurs at these sex steroid concentrations (Piva et al. 1996). Proliferation was measured using the MTT assay. We showed previously (Piva et al. 1996, Rider et al. 1998) that there is a linear relationship between absorbance and cell number under the conditions used in these proliferation assays.

\section{Transient transfections and luciferase expression}

Uterine stromal cells were plated at a density of $1 \times 10^{5}$ in $35 \times 10 \mathrm{~mm}$ culture dishes (Falcon; Fisher Scientific, Pittsburgh, PA, USA). When the cells were approximately $80 \%$ confluent, the growth medium was removed and cells were washed twice in OPTI-MEM medium. Cells were transfected with $2 \mu \mathrm{g}$ of either the dPRP 
promoter-luciferase reporter gene (Orwig et al. 1997, Orwig \& Soares 1999), the pGL-2 basic vector (negative control) or the RSV-luciferase reporter gene (positive control) using the Lipofectamine reagent. A series of dPRP promoter constructs representing $-500,-250,-200$, -147 and -37 bp of DNA in the $5^{\prime}$-flank of the dPRP gene were ligated to the luciferase reporter gene and used in the experiments (Orwig \& Soares 1999). An RSV promoter- $\beta-$ Gal reporter plasmid $(0.5 \mu \mathrm{g})$ was cotransfected to control for transfection efficiency. Cells were incubated in OPTI-MEM low-serum medium alone, or in low-serum medium containing test agents. Cell lysates were collected $48 \mathrm{~h}$ after addition of agents and luciferase and $\beta-G a l$ were measured. Luciferase activity was normalized to $\beta-G$ al by dividing the relative amount of luciferase expression by the amount of $\beta-\mathrm{Gal}$ in the same sample.

\section{Western blot analysis of endogenous dPRP}

Rat uterine stromal cells were cultured for $48 \mathrm{~h}$ in low-serum medium containing progesterone $(1 \mu \mathrm{M})$, estradiol 17- $\beta(10 \mathrm{nM})$, cholera toxin $(10 \mathrm{ng} / \mathrm{ml})$ and IL-11 $(10 \mathrm{ng} / \mathrm{ml})$. Conditioned culture medium and stromal cell extracts were tested for dPRP expression by Western blotting (Rasmussen et al. 1996). As a positive control, CHO cells were stably transfected with the pMSXND expression vector containing the rat dPRP (Rasmussen et al. 1996). Some cells were cultured in low-serum medium without added agents (negative control). The recombinant $\mathrm{dPRP}$ in the $\mathrm{CHO}$-conditioned medium was size fractionated along-side the stromal cell samples using SDS-PAGE. Fractionated proteins were transferred to a nitrocellulose membrane at $4{ }^{\circ} \mathrm{C}$ for $18 \mathrm{~h}$. Non-specific binding sites were blocked using standard methods (Jones et al. 2000). The proteins were reacted with anti-dPRP antibody (1:500) (Rasmussen et al. 1996) for $90 \mathrm{~min}$ at $22{ }^{\circ} \mathrm{C}$. The blots were washed and reacted with goat anti-rabbit alkaline phosphatase secondary antibody (1:1000) (Jackson ImmunoResearch, West Grove, PA, USA). Bound antibody was detected by incubating the blots with $0.3 \mathrm{mg} / \mathrm{ml}$ nitroblue tetrazolium and $0.15 \mathrm{mg} / \mathrm{ml} \mathrm{5-bromo-4-chloro-3-indolyl} \mathrm{phosphate} \mathrm{in}$ $0 \cdot 1 \mathrm{M} \mathrm{NaHCO}_{3}, 10 \mathrm{mM} \mathrm{MgCl}_{2}, \mathrm{pH} 9 \cdot 8$. The size of the reactive bands was determined from prestained molecular size standards (BioRad Laboratories, Hercules, CA, USA).

\section{Immunoprecipitation of cyclin E and cyclin E/Cdk2 kinase activity}

Rat uterine stromal cells were cultured in serum-free medium containing the proliferative agents progesterone $(1 \mu \mathrm{M})$, estradiol $(10 \mathrm{nM})$, and FGF $(50 \mathrm{ng} / \mathrm{ml})$ or medium containing sex steroids with added differentiation agents cholera toxin $(10 \mathrm{ng} / \mathrm{ml})$ and IL-11 $(10 \mathrm{ng} / \mathrm{ml})$ for various time periods $(0-24 \mathrm{~h})$. Stromal cell extracts were prepared by standard methods and the amount of protein in each sample was determined using the BioRad protein assay (Jones et al. 2000). The extracts were incubated with cyclin E agarose-conjugated antibody (Santa Cruz Biotechnology, Inc., Santa Cruz, CA, USA) at $4{ }^{\circ} \mathrm{C}$ for $18 \mathrm{~h}$. The immunoprecipitates were washed and suspended in a kinase buffer $\left(50 \mathrm{mM}\right.$ Hepes, $\mathrm{pH} 7 \cdot 5,10 \mathrm{mM} \mathrm{MgCl}_{2}$, $1 \mathrm{mM}$ dithiothreitol, $0.1 \mathrm{mM}$ sodium orthovanadate, $1 \mathrm{mM}$ EGTA). Histone H1 substrate $(5 \mu \mathrm{g})$ (Upstate Biotechnology, Lake Placid, NY, USA) and an ATP solution containing $\left[\gamma^{32}-\mathrm{P}\right] \mathrm{ATP}(4 \cdot 4 \mu \mathrm{Ci},>4000 \mathrm{Ci} /$ mmol; ICN Biochemicals, Inc., Costa Mesa, CA, USA) were added and the samples were incubated at $30{ }^{\circ} \mathrm{C}$ for $20 \mathrm{~min}$. The reaction was terminated on ice and kinase activity was analyzed by SDS-PAGE (15\% gels). Prestained molecular size standards (BioRad) were electrophoresed on the same gel to determine the size of phosphorylated products. Histone $\mathrm{H} 1$ migrates with an apparent molecular mass of $32 \mathrm{kDa}$. Gels were exposed to $\mathrm{X}$-ray film without intensifying screens for $18 \mathrm{~h}$. The amount of phosphorylated substrate was measured by scanning densitometry. Samples from proliferating and differentiating cells were analyzed on the same blot. The densitometric values were compared with the amount of phosphorylated substrate in quiescent cells (time $0 \mathrm{~h}$ ) on the same blot.

\section{Statistical analysis}

Differences among dPRP promoter activities were determined by non-parametric analysis using the MannWhitney $U$ test. Differences among treatments for the cell proliferation assays were examined by ANOVA, and differences among means were determined through Scheffe's post-hoc test. Differences among Cdk2 kinase activity was determined by the Mann-Whitney $U$ test and time-by-treatment interactions were assessed by matchedpair analysis. A $P$ value $<0 \cdot 05$ was considered statistically significant.

\section{Results}

dPRP gene activation is enhanced by both estradiol and progesterone

In the present study, we tested if the activation response to cholera toxin plus IL-11 was enhanced by sex steroids because these hormones control stromal cell proliferation and differentiation (Rider \& Psychoyos 1994, Lydon et al. 1995, Rider 2002, 2004, Gellersen \& Brosens 2003). dPRP promoter activity increased $(P<0 \cdot 05)$ in cells treated with cholera toxin and IL-11 compared with cells cultured in low-serum medium (Fig. 1). Addition of progesterone to cultures containing differentiation agents (cholera toxin and IL-11) increased $(P<0 \cdot 05)$ promoter activity 8 -fold over the low-serum medium, while the effect of estradiol 


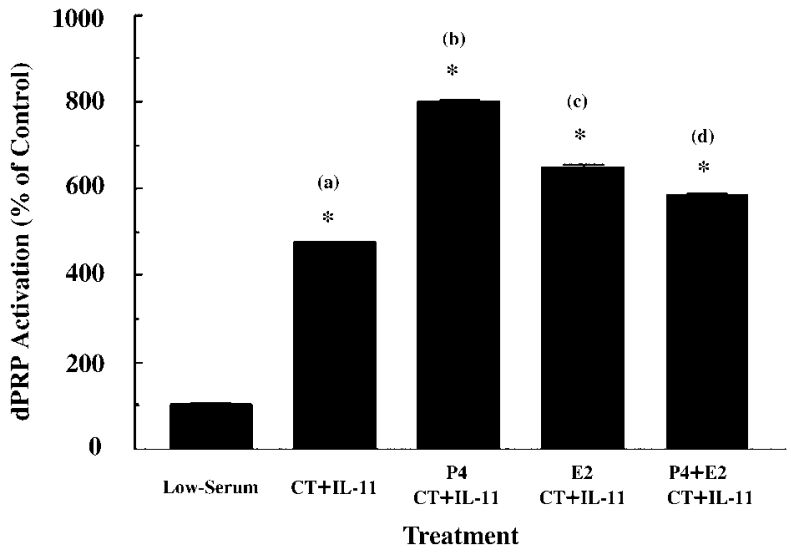

Figure 1 Steroids augment cholera toxin (CT)- and IL-11-dependent dPRP promoter activation. Rat UIII uterine stromal cells were transfected with a 500 bp promoter region of dPRP ligated to a luciferase reporter gene and cultured in low-serum medium containing CT $(10 \mathrm{ng} / \mathrm{ml})$ and IL-11 $(10 \mathrm{ng} / \mathrm{ml})$. Progesterone (P4, $1 \mu \mathrm{M})$, estradiol $17-\beta(\mathrm{E} 2,10 \mathrm{nM})$ and the two steroids together $(\mathrm{P} 4+\mathrm{E} 2)$ were added to some cultures. Data are means \pm S.E.M. of triplicate samples and are representative of three independent experiments. ${ }^{*} P<0.05$ vs low serum medium, Mann-Whitney $U$ test. (a) vs (b), (a) vs (c) and (a) vs (d), $P<0 \cdot 05$, Mann-Whitney $U$ test.

plus the differentiation agents was approximately 6-fold greater $(P<0 \cdot 05)$ than low-serum medium. Addition of progesterone alone, estradiol alone, or the two steroids together, enhanced dPRP promoter activation $(P<0 \cdot 05)$ compared with cholera toxin and IL-11 alone. However, there were no differences in dPRP promoter activation when cells were cultured in medium containing cholera toxin plus IL-11 and either progesterone, estradiol or the two steroids together (Fig. 1).

Uterine stromal cell proliferation is not stimulated by cholera toxin and $I L-11$

In order to test if cholera toxin and IL-11 were stimulating differentiation, as assessed by dPRP promoter activation, and not simply increasing the number of uterine stromal cells in culture, the effects of these agents on cell proliferation was measured. Using the MTT assay that has been validated in our laboratory (Piva et al. 1996, Rider et al. 1998) we measured the effects of cholera toxin and IL-11 on cell proliferation. Progesterone plus FGF and progesterone and estradiol plus FGF increased $(P<0.05)$ uterine stromal cell proliferation over quiescent cells (Fig. 2). Consistent with our previous observations (Piva et al. 1996) estradiol plus FGF without progesterone did not stimulate proliferation $(P>0 \cdot 05)$. Stromal cells cultured with cholera toxin and IL-11 did not proliferate $(P>0 \cdot 05)$ compared with quiescent cells (serum-free medium).

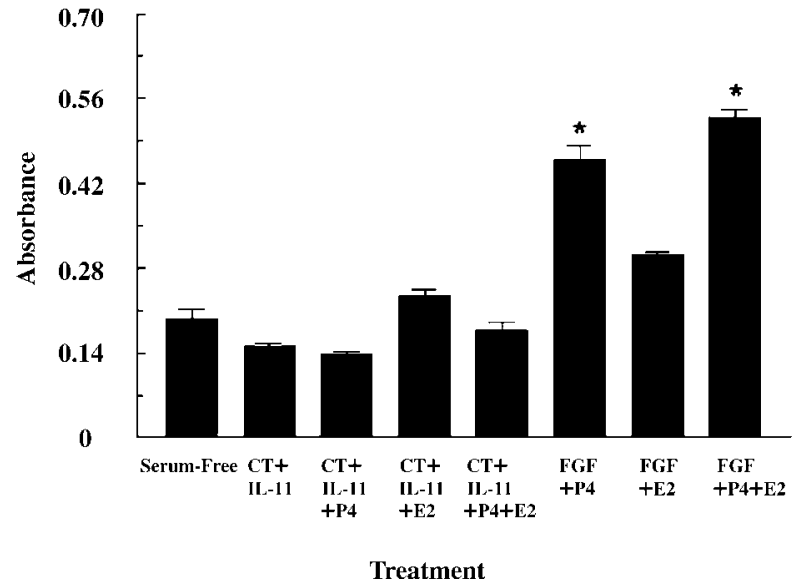

Figure 2 Uterine stromal cell proliferation is not stimulated by cholera toxin $(C T)(10 \mathrm{ng} / \mathrm{ml})$ and IL-11 $(10 \mathrm{ng} / \mathrm{ml})$. Quiescent UIII uterine stromal cells were stimulated to re-enter the cell cycle by addition of serum-free medium containing the indicated agents. Cell proliferation was measured by the use of the MTT assay. Data are means \pm S.E.M. of six independent observations. ${ }^{*} P<0 \cdot 05$, ANOVA with Scheffé's post-hoc test compared with serum-free control. Abbreviations: P4, progesterone; E2, estradiol 17- $\beta$.

Addition of progesterone and/or estradiol to cell cultures containing cholera toxin and IL-11 did not stimulate the proliferative response $(P>0 \cdot 05)$. Together, these results indicate that cholera toxin and IL-11 do not increase dPRP promoter activation by stimulating proliferation of uterine stromal cells.

Sex steroids, cholera toxin and IL-11 stimulate expression of endogenous $d P R P$

Previous research in our laboratory showed that dPRP is not expressed in these rat uterine stromal cell lines in culture (Orwig et al. 1997). It was expected, however, that endogenous expression of dPRP would be stimulated in stromal cells cultured with steroids and differentiation agents. To test this postulate, stromal cells were cultured in medium containing cholera toxin and IL-11 plus sex steroids. Activation of endogenous dPRP expression was analyzed by Western blotting (Fig. 3). A single reactive species was observed in stromal cell extracts (lane 3), and the size of this protein was consistent with dPRP from $\mathrm{CHO}$ cells engineered to express recombinant dPRP (positive control, lane 2). Over the $48 \mathrm{~h}$ period of culture, dPRP was not secreted in detected amounts into the culture medium from these same uterine stromal cells stimulated with sex steroids, cholera toxin and IL-11 (lane 4). Stromal cells transfected with dPRP-500 and cultured for $48 \mathrm{~h}$ in low-serum medium did not express detected 


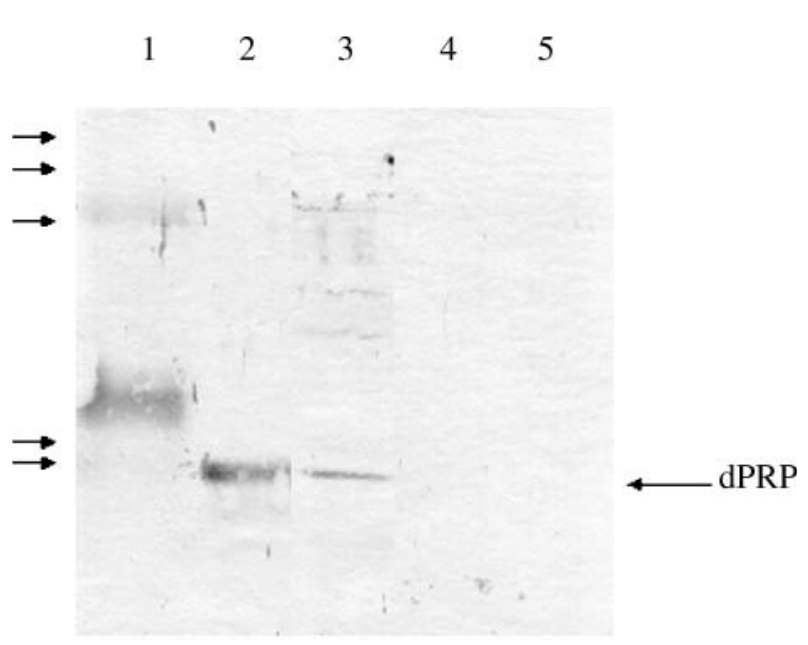

Figure 3 Sex steroids, cholera toxin and IL-11 stimulate expression of endogenous dPRP protein. Rat UIII uterine stromal cells were cultured for $48 \mathrm{~h}$ in low-serum medium containing progesterone $(1 \mu \mathrm{M})$, estradiol $17-\beta(10 \mathrm{nM})$, cholera toxin $(10 \mathrm{ng} / \mathrm{ml})$ and IL-11 $(10 \mathrm{ng} / \mathrm{ml})$. Endogenous dPRP protein expression was analyzed by Western blotting. Lane 1, prestained molecular size markers (BioRad); lane 2, conditioned medium (10 $\mu \mathrm{l})$ from $\mathrm{CHO}$ cells expressing recombinant dPRP (positive control); lane 3, rat UIII stromal (decidual) cell extract $(100 \mu \mathrm{g})$; lane 4 , rat UIII stromal (decidual) cell culture supernatant $(100 \mu \mathrm{g})$; lane 5, UIII stromal cell extract $(100 \mu \mathrm{g})$ from stromal cells cultured in low-serum medium without sex hormones, cholera toxin and IL-11 for $48 \mathrm{~h}$ (negative control). Left arrows indicate position of prestained molecular size markers at 218, 125, 78, 44 and $31 \mathrm{kDa}$.

dPRP protein (lane 5) showing that endogenous dPRP expression was not activated by the transfection of the dPRP-luciferase reporter construct.

\section{Dissection of differentiation-dependent responsive regions in the} dPRP promoter

In primary decidual cells, maximal activation of dPRP occurred in the upstream region of dPRP-500 (Orwig \& Soares 1999). We postulated that activation of dPRP in differentiating stromal cells could involve the same $5^{\prime}-$ region that is active in primary decidual cells. To pinpoint the responsive region of the dPRP promoter stimulated by the differentiation agents used in these experiments, $5^{\prime}$ deleted promoter fragments were transfected into UIII uterine stromal cells (Fig. 4). Stromal cells were cultured for $48 \mathrm{~h}$ in medium containing sex steroids, cholera toxin and IL-11 and at the end of culture luciferase expression was measured. Four of the five promoter regions showed increased $(P<0 \cdot 05)$ dPRP activation compared with the low-serum control. There was a 5-fold increase in dPRP activation when cells containing the contiguous $-500 \mathrm{bp}$ promoter were cultured in medium containing sex steroids and differentiation agents compared with low-serum medium (Fig. 4). There was an additional 1.6-fold numerical increase in dPRP

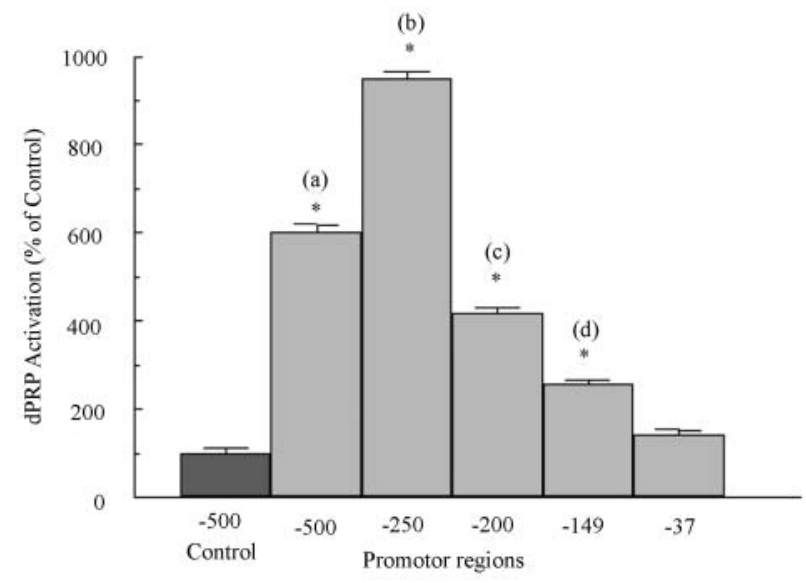

Figure 4 Dissection of differentiation-dependent responsive regions in the dPRP promoter. Uterine UIII stromal cells were transfected with a 500 bp dPRP promoter and various $5^{\prime}$-deleted promoter segments as indicated ligated to a luciferase reporter gene. The cells were cultured in low-serum medium containing progesterone $(1 \mu \mathrm{M})$, estradiol $17-\beta(10 \mathrm{nM})$, cholera toxin $(10 \mathrm{ng} / \mathrm{ml})$ and IL-11 $(10 \mathrm{ng} / \mathrm{ml})$ for $48 \mathrm{~h}$. Cell extracts were collected and dPRP promoter activity was assessed by measuring luciferase expression. Data are means \pm S.E.M. of samples in triplicate and are representative of two independent assays. ${ }^{*} P<0.05$ vs control, Mann-Whitney $U$ test. (a) vs (c), (a) vs (d), (b) vs (c) and (b) vs (d), $P<0 \cdot 05$, Mann-Whitney $U$ test.

activation to differentiation agents and hormones when the proximal promoter $(-250 \mathrm{bp})$ was compared with the contiguous $-500 \mathrm{bp}$ fragment, but this difference was not significant $(P>0 \cdot 05)$. There was approximately a 5 -fold difference $(P<0.05)$ in promoter activity between -200 and $-250 \mathrm{bp}$, suggesting a major stimulatory element between -200 and $-250 \mathrm{bp}$ of the dPRP promoter.

\section{Increased cyclin E/Cdk2 activity in differentiating uterine stromal cells}

To test if the temporal changes in cyclin $\mathrm{E}$ expression in vivo (Potapova \& Rider 2003) correlated with increased Cdk2 activity in vitro, we compared cyclin E/Cdk2 activity in proliferating (treated with sex hormones and FGF) and differentiating (treated with sex steroids, cholera toxin and IL-11) UIII uterine stromal cells (Fig. 5). The cyclin E/Cdk2 activity was detected as a single phosphorylated species consistent with the expected mass $(32 \mathrm{kDa})$ for histone $\mathrm{H} 1$ substrate (Fig. 5A). The amount of cyclin E/Cdk2 activity in quiescent cells (time $0 \mathrm{~h}$ ) was measured and compared on the same blot with the amount of activity in cells stimulated to proliferate (sex hormones and FGF) and differentiate (sex steroids, cholera toxin and IL-11). The adjusted values at each time point were 
(A)

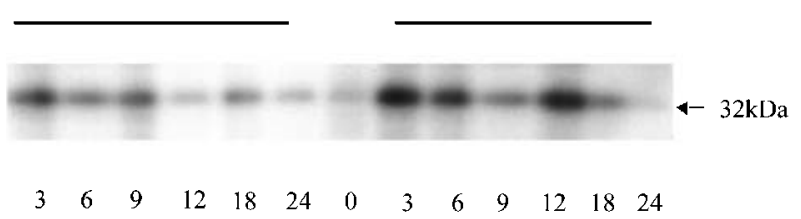

Time After Stimulation (h)

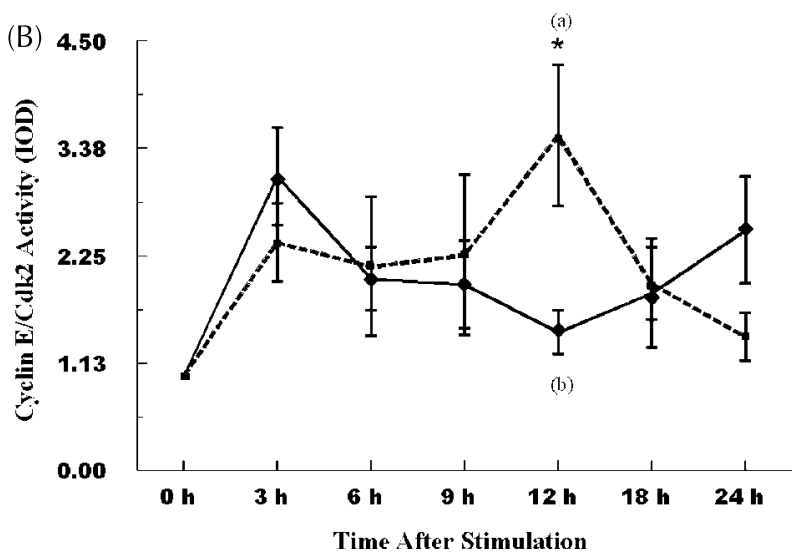

Figure 5 Changes in cyclin E/Cdk2 kinase activity in proliferating and differentiating UIII uterine stromal cells. Quiescent uterine stromal cells were cultured in low-serum medium containing progesterone (P4) $(1 \mu \mathrm{M})$ and estradiol 17- $\beta$ (E2) (10 nM). Cultures of proliferating cells also contained FGF $(50 \mathrm{ng} / \mathrm{ml})$, while cultures of differentiating cells also contained cholera toxin (CT) (10 ng/ml) and IL-11 $(10 \mathrm{ng} / \mathrm{ml})$. Cell extracts were collected $48 \mathrm{~h}$ after stimulation and cyclin E/Cdk2 complexes were immunoprecipitated using a cyclin E antibody. Substrate phosphorylation was determined as detailed in the text. (A) Representative blot showing the temporal changes in phosphorylation of added histone $\mathrm{H} 1$ substrate $(5 \mu \mathrm{g})$ migrating with an apparent molecular mass of $32 \mathrm{kDa}$ (shown by arrow). (B) Quantitative analysis indicates increased cyclin E/Cdk2-dependent substrate phosphorylation in differentiating compared with proliferating stromal cells at $12 \mathrm{~h}$ post-stimulation. Data are means \pm s.E.M. adjusted values from samples measured in three independent assays and stromal cell passages. The solid line shows data from proliferating cells (progesterone, estradiol and FGF) and the broken line shows data from differentiating cells (progesterone, estradiol, cholera toxin, and IL-11). IOD, integrated optical density. ${ }^{*} P<0 \cdot 05$, compared with quiescent cells (time $0 \mathrm{~h}$ ), Mann-Whitney $U$ test. (a) vs (b), $P<0 \cdot 05$, matched-pair analysis.

measured in three independent assays and from three separate stromal cell passages. The results (Fig. 5B) revealed a similar pattern of Cdk2-dependent phosphorylation between 3 and $6 \mathrm{~h}$ in cells stimulated to proliferate (treated with progesterone, estradiol and FGF) or differentiate (treated with progesterone, estradiol, cholera toxin and IL-11). Although the amount of activity increased numerically at this time, the differences were not significant $(P>0 \cdot 05)$ compared with the quiescent cells. However, at $9 \mathrm{~h}$ post-stimulation, cyclin $\mathrm{E} / \mathrm{Cdk} 2$ activity began increasing in differentiating cells but not in proliferating cells. This difference continued such that cyclin E/Cdk2 phosphorylation activity increased $(P<0 \cdot 05)$ in stromal cells stimulated with progesterone, estradiol, cholera toxin and IL-11 compared with quiescent cells (Fig. $5 \mathrm{~B})$. Moreover, there was a 3 -fold increase $(P<0 \cdot 05)$ in phosphorylation activity at $12 \mathrm{~h}$ in differentiating compared with proliferating cells. At 18 and $24 \mathrm{~h}$ poststimulation the relative amount of histone $\mathrm{H} 1$ phosphorylation declined approximately 2-fold compared with that at $12 \mathrm{~h}$ and was similar between proliferating and differentiating cells.

\section{Discussion}

In the present study we have stimulated UIII rat uterine stromal cells to differentiate in culture using agents that are known to be required for differentiation in vivo. In order to study the underlying molecular mechanisms that promote differentiation, dPRP was utilized as a marker gene for differentiation events in vitro. Increased dPRP promoter activity in differentiating UIII stromal cells was not due to increased proliferation. Moreover, in response to differentiation agents a detectable amount of endogenous dPRP protein was induced. Thus, the agents known to stimulate differentiation in vivo activate dPRP in cultured UIII rat uterine stromal cells. Together, these data show that the UIII rat uterine stromal cell line expresses a differentiation-specific marker (dPRP) in response to sex steroids and agents shown to be required for decidualization in vivo. We have utilized this model to gain new insight into cell cycle regulatory mechanisms that are utilized by stromal cells entering the differentiation pathway. Comparisons between proliferating and differentiating UIII stromal cells show that cyclin E/Cdk2 activity increases in differentiating cells. These results are consistent with the view that cyclin E/Cdk2 could serve as a molecular switch for cellular entry into the differentiation pathway.

In pregnant rats, $\mathrm{dPRP}$ is expressed primarily in the anti-mesometrial decidual cells (Roby et al. 1993, Orwig et al. 1997, Rasmussen et al. 1997). The factors that regulate the cell-specific dPRP expression in decidual cells are not known. However, previous studies from our laboratory (Orwig \& Soares 1999) showed that a $93 \mathrm{bp}$ dPRP promoter was sufficient to drive expression in primary decidual cells. Two candidate regulators within this $93 \mathrm{bp}$ promoter were identified as AP-1 and Ets. Deletion analysis of the binding sites for either the AP-1 or 
Ets decreased promoter activity. The present results show that in the UIII rat uterine stromal cell line, factors stimulating decidual cell differentiation stimulate the dPRP promoter when it contained at least $149 \mathrm{bp}$ of the dPRP promoter. Complex regulation of the dPRP promoter may include differences in early differentiating cells (this report) when compared with cells that have more fully differentiated (Orwig \& Soares 1999). Previous experiments and the current data suggest that the dPRP promoter is not effectively activated in uterine stromal cells. However, when the stromal cells are stimulated to differentiate into decidual cells using cholera toxin, IL-11 and sex steroids, dPRP promoter is activated. Moreover, in both primary decidual cells and UIII decidual cells stimulated to differentiate in vitro, maximal activation occurs within the $250 \mathrm{bp}$ dPRP and the $500 \mathrm{bp}$ dPRP regions. Together these data suggest that major regulatory elements within this region of the promoter are required for activating and maintaining expression of dPRP in differentiating cells. Continued dPRP expression in primary decidual cells may require additional elements located in the proximal promoter as suggested from our earlier study (Orwig \& Soares 1999).

Cyclin E is considered a G1 cyclin that is regulated by autonomous mechanisms (Dulic et al. 1992). Cyclin E expression peaks at the G1/S phase border and cyclin E/Cdk2 kinase activity completes the phosphorylation of retinoblastoma protein initiated by the D-type cyclins (Lundberg \& Weinberg 1998). There are two E-type cyclins that share $75 \%$ amino acid sequence similarity within the cyclin box and are normally co-expressed in proliferating cells (Geng et al. 2001). Mice lacking both cyclin E1 and cyclin E2 by gene targeted mutagenesis show defects primarily in the cardiovascular system and the placenta (Geng et al. 2003, Parisi et al. 2003). Of particular relevance for stromal cell differentiation studied here, is the failure of the trophoblast giant cells and the megakaryocytes to undergo endoreplication in the cyclin E null mice (Geng et al. 2003, Parisi et al. 2003). In both of these cell types endoreplication is required for terminal differentiation. Central to the differentiation cascade in uterine stromal cells is the process of endoreplication that involves the uncoupling of DNA replication from mitosis. Decidual nuclei in the anti-mesometrial aspect of the endometrium, where implantation is initiated, are polyploid. The chromosomes fail to separate at metaphase and increased ploidy from 4 to $32 \mathrm{~N}$ is reported (McConnel et al. 1982). Our results indicate that differences in the quantity and the timing of cyclin E/Cdk2 activity occurs in uterine stromal cells stimulated to differentiate. It will now be of interest to investigate if changes in cyclin E/Cdk2-dependent phosphorylation could serve as a molecular switch for cells that use endoreplication as part of the differentiation process.

It is interesting to speculate about the mechanisms of the E-type cyclins as molecular switches for differentiating cells. In general, the E-type cyclins regulate events necessary for $\mathrm{S}$ phase of the cell cycle including DNA replication (Arata et al. 2000), centrosome duplication (Okuda et al. 2000) and histone biosynthesis (Ma et al. 2000). These processes, however, would be required for proliferating as well as differentiating cells. In cells lacking cyclins E1/E2, but continuously able to progress through the cell cycle, the formation of pre-replication complexes was normal, as measured by the loading of minichromosome maintenance protein 2 (MCM2), origin replication complex 2 protein and CDC6 protein (Geng et al. 2003). In contrast, mutant cells lacking cyclin E1/E2 that were not continuously cycling were unable to load MCM2 on the DNA, although the levels of MCM2 protein in the cells was similar to that in continuously proliferating cells (Geng et al. 2003). The association and dissociation of the MCM proteins from chromatin may control the competence of DNA for replication. Proteins required for the formation of the pre-replication complex are conserved across species. In non-mammalian species, a role for MCMs in stimulating DNA replication in the endoreplication cycles of Drosophila larval salivary glands has been reported (Su \& O'Farrell 1997). Cyclin E stimulated the association of MCM2 to Drosophila polytene nuclei during endoreplication (Su \& O'Farrell 1997).

In conclusion, we now possess an in vitro model system that can be used to identify the signal transduction pathways and molecular mechanisms that control uterine stromal cell proliferation and differentiation. Our results indicate that cyclin $\mathrm{E} / \mathrm{Cdk} 2$ activity increases as uterine stromal cells differentiate. These findings are consistent with the idea that cyclin E could serve as a molecular switch for cells exiting the proliferative cycle and entering the differentiation pathway.

\section{Funding}

This research was funded in part by grants from the National Science Foundation (IBN-0091504) to V R, the National Institutes of Health (HD-39878) to M J S and NIHRR-16475 by the Biomedical Research Infrastructure Network Program of the National Center for Research Resources. The authors declare that there is no conflict of interest that would prejudice the impartiality of this scientific work.

\section{References}

Amaroso EC 1952 Placentation. In Marshall's Physiology of Reproduction, pp 127-311. Ed. AS Parks. London: Longmans.

Arata Y, Fujita M, Ohtani K, Kijima S \& Kato JY 2000 Cdk2-dependent and -independent pathways in E2F-mediated S phase induction. Journal of Biological Chemistry 275 6337-6345.

Ashkar AA, DiSanto JP \& Croy BA 2000 Interferon $\gamma$ contributes to initiation of uterine vascular modification, decidual integrity, and uterine natural killer cell maturation during normal murine pregnancy. Journal of Experimental Medicine 192 259-270. 
Bell SC 1983 Decidualization: regional differentiation and associated function. Oxford Reviews in Reproductive Biology 5 220-271.

Berwaer M, Martial JA \& Davis JRE 1994 Characterization of an up-stream promoter directing extrapituitary expression of the human prolactin gene. Molecular Endocrinology 8 635-642.

Bilinski P, Roopenian D \& Gossler A 1998 Maternal IL-11R alpha function is required for normal decidual and fetoplacental development in mice. Genes and Development 12 2234-2243.

Chang MC 1950 Development and fate of transferred rabbit ova or blastocyst in relation to the ovulation time of recipients. Journal of Experimental Zoology 114 197-225.

Christian M, Marango P, MakI, McVey J, Varker F, White J \& Brosens JJ 2001 Interferon- $\gamma$ modulates prolactin and tissue factor expression in differentiating human endometrial stromal cells. Endocrinology 142 3142-3151.

Dimitriadis E, Robb L \& Salamonsen LA 2002 Interleukin 11 advances progesterone-induced decidualization of human endometrial stromal cells. Molecular Human Reproduction 8 636-643.

Dulic V, Lees E \& Reed SI 1992 Association of human cyclin E with a periodic G1-S phase protein kinase. Science 257 1958-1961.

Gellersen B \& Brosens J 2003 Cyclic AMP and progesterone receptor cross-talk in human endometrium: a decidualizing affair. Journal of Endocrinology 178 357-372.

Gendron RL, Paradis H, Hsieh-Li HM, Lee DW, Potter SS \& Markoff E 1997 Abnormal uterine stromal and glandular function associated with maternal reproductive defects in Hoxa-11 mice. Biology of Reproduction 56 1097-1105.

Geng Y, Yu Q, Whoriskey W, Dick F, Tsai KY, Ford HL, Biswas DK, Pardee AB, Bruno Amati B, Jacks T et al. 2001 Expression of cyclin E1 and E2 during mouse development and in neoplasia. PNAS 98 13138-13143.

Geng Y, Yu Q, Sicinska E, Das M, Schneider JE, Bhattacharya S, Rideout WM, Bronson RT, Gardner H \& Sicinski P 2003 Cyclin E ablation in the mouse. Cell 114 431-443.

Irwin JC, Kirk D, King RJB, Quigley MM \& Gwatkin RBL 1989 Hormonal regulation of human endometrial stromal cells in culture: an in vitro model for decidualization. Fertility and Sterility $\mathbf{5 2}$ 761-768.

Jones SR, Kimler BF, Justice WM \& Rider V 2000 Transit of normal rat uterine stromal cells through G1 phase of the cell cycle requires progesterone-growth factor interactions. Endocrinology 141 637-648.

Kennedy TG 1983 Prostaglandin $\mathrm{E}_{2}$, adensosine 3',5'-cyclic monophosphate and changes in endometrial vascular permeability in rat uteri sensitized for the decidual cell reaction. Biology of Reproduction 29 1069-1076.

Kennedy TG 1985 Evidence for the involvement of prostaglandins throughout the decidual cell reaction in the rat. Biology of Reproduction 33 140-146.

Li R, Hartley L \& Robb L 2001 Cloning of rat interleukin 11 and interleukin 11 receptor alpha chain and analysis of their expression in rat uterus in the peri-implantation period. Reproduction 122 593-600.

Lim H, Paria BC, Das SK, Dinchuk JE, Langenbach R, Trzaskos JM \& Dey SK 1997 Multiple female reproductive failure in cyclooxygenase 2-deficient mice. Cell 91 197-208.

Lockwood CJ, Nemerson Y, Guller S, Krukun G, Alvarez M, Hausknecht V, Gurpide E \& Schatz F 1993 Progestational regulation of human endometrial stromal cell tissue factor expression during decidualization. Journal of Clinical Endocrinology and Metabolism 76 231-236.

Lundberg AS \& Weinberg RA 1998 Functional inactivation of the retinoblastoma protein requires sequential modification by at least two distinct cyclin-cdk complexes. Molecular and Cellular Biology 18 753-761.

Lydon JP, DeMayo FJ, Funk CR, Mani SK, Hughtes AR, Montgomery CA Jr, Shyamala G, Conneely OM \& O'Mallery BW
1995 Mice lacking progesterone receptor exhibit pleiotropic reproductive abnormalities. Genes and Development 9 2266-2278.

Ma T, Van Tine BA, Wei Y, Garrett MD, Nelson D, Adams PD, Wang J, Qin J, Chow LT \& Harper JW 2000 Cell cycle-regulated phosphorylation of p220 (NPAT) by cyclin E/Cdk2 in Cajal bodies promotes histone gene transcription. Genes and Development $\mathbf{1 4}$ 2298-2313.

McConnel KN, Sillar RG, Young BD \& Green B 1982 Ploidy and progesterone-receptor distribution in flow sorted deciduomal nuclei. Molecular and Cellular Endocrinology 25 99-104.

Okuda M, Horn HF, Tarapore P, Tokuyama Y, Smulian AG, Chan PK, Knudsen ES, Hofmann IA, Snyder JD, Bove KE et al. 2000 Nucleoplasmin/B23 is a target of $\mathrm{Cdk} 2 /$ cyclin $\mathrm{E}$ in centrosome duplication. Cell 103 127-140.

Orwig KE \& Soares MJ 1999 Transcriptional activation of the decidual/trophoblast prolactin-related protein gene. Endocrinology $1404032-4039$.

Orwig KE, Dai G, Rasmussen CA \& Soares MJ 1997 Decidual/trophoblast prolactin-related protein: characterization of gene structure and cell-specific expression. Endocrinology 138 $2491-2500$

Öztürk A, Fresnoza A, Savoi A, Duckworth HW \& Duckworth ML 2003 Defining regulatory region in the rat prolactin gene family locus using a large P1 genomic clone. Endocrinology 144 4742-4754.

Parisi T, Beck AR, Rougier N, McNeil T, Lucian L, Werb Z \& Amati B 2003 Cyclin E1 and E2 are required for endoreplication in placental trophoblast giant cells. EMBO J 22 4794-4803.

Peterson JW, Saini SS, Dickey WD, Klimpel GR, Bomalaski JS, Clark MA, Xu X-J \& Chopra AK 1996 Cholera toxin induces synthesis of phospholipase A2-activating protein. Infection and Immunity 64 2137-2143

Pijnenborg R, Robertson WB, Brosens I \& Dixon G 1981 Review article: trophoblast invasion and the establishment of haemochorial placentation in man and laboratory animals. Placenta 2 71-92.

Piva M, Fleiger O \& Rider V 1996 Growth factor control of cultured rat uterine stromal cell proliferation is progesterone dependent. Biology of Reproduction 55 1333-1342.

Potapova TA \& Rider V 2003 Hormonal control of cyclin E in uterine stroma. Molecular Biology of the Cell 14 416a.

Psychoyos A 1973 Endocrine control of egg implantation. In Handbook of Physiology, pp 187-215. Eds RO Greep, EG Astwood \& SR Geiger. Baltimore: Williams and Wilkins.

Rankin JC, Ledford BE \& Baggett B 1988 Early involvement of cyclic nucleotides in the artificially stimulated decidual cell reaction in the mouse uterus. Biology of Reproduction 17 549-554.

Rasmussen CA, Hashizume K, Orwig KE, Xu L \& Soares MJ 1996 Decidual prolactin-related protein: heterologous expression and characterization. Endocrinology 137 5558-5566.

Rasmussen CA, Orwig KE, Vellucci S \& Soares MJ 1997 Dual expression of prolactin-related protein in decidual and trophoblast tissues during pregnancy. Biology of Reproduction 55 647-654.

Rider V 2002 Progesterone and the control of uterine cell proliferation and differentiation. Frontiers in Bioscience 7 D1545-D1555.

Rider V 2004 Isolation of hormone responsive uterine stromal cells. An in vitro model for stromal cell proliferation and differentiation. In Placenta Methods and Protocols. Eds MJ Soares \& J Hunt. Totowa, NJ: Humana Press. (In Press).

Rider V \& Psychoyos A 1994 Inhibition of progesterone receptor function results in loss of basic fibroblast growth factor expression and stromal cell proliferation during uterine remodelling in the pregnant rat. Journal of Endocrinology 140 239-249.

Rider V, Kimler BF \& Justice WM 1998 Progesterone-growth factor interactions in uterine stromal cells. Biology of Reproduction $\mathbf{6 6}$ 188-193.

Robb L, Li R, Hartley L, Nandukar HH, Koentgen F \& Begley CG 1998 Infertility in female mice lacking the receptor for interleukin-11 is due to a defective uterine response to implantation. Nature Medicine 4 303-308. 
Roby KF, Deb S, Gibori G, Szpirer C, Levan G, Kwok SCM \& Soares MJ 1993 Decidual prolactin related protein: identification, molecular cloning, and characterization. Journal of Biological Chemistry 268 3136-3142.

Salamonson LA, Dimitriadis E, Jones RL \& Nie G 2003 Complex regulation of decidualization: a role for cytokines and proteases. A review. Placenta 24 S76-S85.

Soares MJ \& Linzer DIH 2001 The rodent prolactin family and pregnancy. In Prolactin, pp 139-167. Ed. ND Horseman. Norwell, MA: Kluwer Academic Publisher.

Su TT \& O'Farrell PH 1997 Chromosome association of minichromosome maintenance protein in Drosophila mitotic cycles. Journal of Cell Biology 139 13-21.

Telgmann R \& Gellersen B 1998 Marker genes of decidualization: activation of the decidual prolactin gene. Human Reproduction Update 4 472-479.

Tseng L, Gao JG, Chen R, Zhu HH, Mazella J \& Powell DR 1992 Effect of progestin, antiprogestin, and relaxin on the accumulation of prolactin and insulin-like growth factor-binding protein-1 messenger ribonucleic acid in human endometrial stromal cells. Biology of Reproduction 47 441-450.

Wang D, Ishimura R, Walia DS, Müller H, Dai G, Hunt JS, Lee NA, Lee JJ \& Soares MJ 2000 Eosinophils are cellular targets of the novel uteroplacental heparin-binding cytokine decidual/trophoblast prolactin-related protein. Journal of Endocrinology 167 15-28.

Wiemers DO, Shao L-J, Ain R, Dai G \& Soares MJ 2003 The mouse prolactin gene family locus. Endocrinology 144 313-325.

Yao MW, Lim H, Schust DJ, Choe SE, Farago A, Ding Y, Michaud S, Church GM \& Maas RL 2003 Gene expression profiling reveals progesterone-mediated cell cycle and immunoregulatory roles of Hoxa-10 in the preimplantation uterus. Molecular Endocrinology 17 $610-627$.

Received 28 September 2004

Accepted 14 October 2004

Made available online as an

Accepted Preprint 21 October 2004 